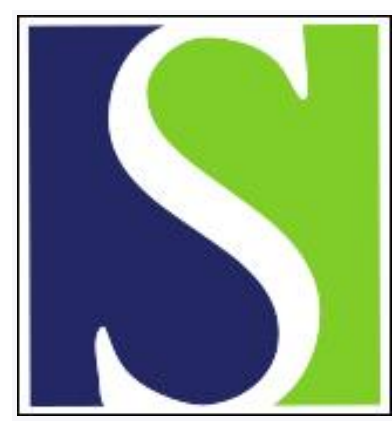

Scand J Work Environ Health 2000;26(3):273-278

https://doi.org/10.5271/sjweh.542

Issue date: Jun 2000

Downsizing and industrial restructuring in relation to changes in psychosocial conditions of work in British Columbia sawmills

by Ostry A, Marion S, Green LW, Demers P, Teschke K, Hershler R, Kelly S, Hertzman C

The following article refers to this text: 2001;27(1):70-75

Key terms: industrial restructuring; psychosocial work conditions; sawmill; unemployment

This article in PubMed: www.ncbi.nlm.nih.gov/pubmed/10901121 


\title{
Downsizing and industrial restructuring in relation to changes in psychosocial conditions of work in British Columbia sawmills
}

\author{
by Aleck Ostry, PhD, ${ }^{1}$ Stephen Marion, MD, ${ }^{1}$ Lawrence W Green, Dr PH, ${ }^{1,2}$ Paul Demers, PhD, ${ }^{1}$ Kay \\ Teschke, PhD, ${ }^{1}$ Ruth Hershler, MSc, ${ }^{1}$ Shona Kelly, BSc, ${ }^{1}$ Clyde Hertzman, MD ${ }^{1,3}$
}

\begin{abstract}
Ostry A, Marion S, Green LW, Demers P, Teschke K, Hershler R, Kelly S, Hertzman C. Downsizing and industrial restructuring in relation to changes in psychosocial conditions of work in British Columbia sawmills. Scand $J$ Work Environ Health 2000;26(3):273-278.
\end{abstract}

\begin{abstract}
Objectives This paper investigates changes in the psychosocial and physical work conditions of the sawmill industry in British Columbia, Canada, over the past 35 years.

Methods Shifts in work conditions were examined within the context of historical changes in sawmill labor demography and job taxonomy as the industry was both downsized and restructured, largely in response to an economic recession in the early 1980 s.

Results and conclusions Downsizing eliminated approximately $60 \%$ of the work force and $1 / 4$ of sawmill job titles. Although all the job categories in restructured sawmills showed increased levels of control, the gradient in control across job categories was steeper in 1997 than in 1965; this change may have important health implications particularly for the unskilled workers in the restructured mills.
\end{abstract}

Key terms industrial restructuring, psychosocial work conditions, sawmills, unemployment.

Since the 1970 s many industries in the developed world have gone through restructuring as economies adapt to globalization (1). This process has hit traditional male blue-collar industries particularly hard, such that large segments of this work force have been exposed to the threat of unemployment, the experience of unemployment, and, for those who survive downsizing, exposure to a new set of psychosocial conditions in restructured tasks and organizations (2).

Beginning in early 1981, the province of British Columbia suffered a major recession, during which the unemployment rate rose from $6.7 \%$ to a peak of $14.7 \%$ in 1984 and was particularly severe in the sawmill industry $(3,4)$. In response to this recession and shifts in the postrecession market conditions, many sawmills instituted technological changes and laid off workers. According to Barnes \& Hayter $(5,6)$ these technological and labor force changes represent an irreversible shift from a postwar industrial strategy that was labor intensive to one that is increasingly capital intensive.
This paper investigates how psychosocial and physical work conditions have changed in the sawmill industry in British Columbia, Canada, during the past 35 years. Shifts in work conditions are examined within the context of historical changes in sawmill labor demography and job taxonomy as the industry was both downsized and restructured, largely in response to an economic recession which occurred during the early 1980 s.

\section{Subjects and methods}

This investigation is based on a cohort of approximately 29000 sawmill workers who worked for at least 1 year between 1950 and 1997 in 1 of 14 sawmills in British Columbia.

\section{Sawmill cohort}

The sawmill cohort was originally gathered to investigate the effect of chlorophenol antisapstain chemicals on

1 Department of Health Care and Epidemiology, University of British Columbia, Vancouver BC, Canada.

2 Institute of Health Promotion, University of British Columbia, Vancouver BC, Canada.

3 The Population Health Program of the Canadian Institute of Advanced Research, Toronto, Ontario, Canada.

Reprint requests to: Dr Aleck Ostry, Department of Health Care and Epidemiology, 5804 Fairview Avenue, Vancouver BC, V6T 1W5, Canada. [E-mail: ostry@interchange.ubc.ca] 
sawmill workers $(7,8)$. The job history data included all job start and end dates and job titles for workers during their employment at a study sawmill. As well, personal identifying data such as birth date were available. Employment by mill and year were calculated using the job start and termination dates.

All the job titles during the study period were resolved to 86 basic sawmill job titles by a panel of experienced workers and managers (9). These 86 job titles were, in turn, reduced to 5 basic categories (clerical, managers, maintenance, unskilled, and skilled workers). The change in the relative proportion of these 5 categories was calculated for each decade (1950s through $1990 \mathrm{~s}$ ) as a means of estimating the effect of restructuring on the distribution of the basic job categories over time.

\section{Estimating the psychosocial work conditions}

In most studies psychosocial work conditions are estimated using worker self-reports (10). In this investigation, psychosocial work condition scores were determined using expert raters with long experience, who rated jobs retrospectively for the year 1965 and currently for the year 1997 in order to determine pre- and postrestructuring psychosocial work conditions (9).

A union-management system of job evaluation has been in place in the sawmill industry in British Columbia since the late 1960 s. This job evaluation system relies on an instrument, developed "in house", which measures psychological and physical demand, control over one's use of skill, control over one's decision making, and physical and other hazards to which workers may be exposed. This instrument is very similar to the demandcontrol instrument developed by Robert Karasek and his co-workers (11) so that the expert evaluators were familiar with the dimensions used in this model and with applying them to assessments of sawmill job titles.

Six job evaluators with over 20 years' experience in sawmill job evaluation in British Columbia were potential interviewees. Three were currently employed by industry, 1 being currently employed by the union, and 2 being recently retired from the union. All 3 industry raters agreed to participate, as did the currently employed union expert. One of the retired union experts was too ill to participate, and the other refused without giving a reason. Each of the 4 participants had over 30 years' experience. They were blinded to the purpose of the study but were told that it was part of a broad investigation of the impact of new technology in the industry.

Each expert rated the psychosocial work conditions independently. First, they were asked to rate 86 job titles in a "typical" coastal sawmill in 1965 using a shortened, 13-question version of Karasek's questionnaire (appendix). Although the questionnaire had been shortened to reduce interview time, the interviews still averaged 3.5 hours because of the number of job titles at issue and the number of items asked per job title. To test intrarater reliability, $10 \%$ of the jobs were randomly selected from the job title list and re-presented to the raters towards the end of the interview.

Three months after these interviews the same 4 expert raters were reinterviewed to estimate current (1997) psychosocial job conditions, using the same questionnaire. Because some of the job titles extant in 1965 had been eliminated or were extremely rare in the industry due to restructuring, 60 job titles were estimated instead of the 86 job titles estimated in the first interview. Ten percent of the jobs were randomly selected from the job title list and re-presented to the raters towards the end of the interview to test for intrarater reliability.

For both interviews the following 5 variables were measured: control, psychological demand, physical demand, noise, and co-worker social support. With the exception of co-worker social support, all the questions were derived from Karasek's original questionnaire (11). The 2 questions on co-worker social support were obtained from the Swedish version of Karasek's questionnaire (12). Estimations of psychosocial job conditions were compared to determine the change in these conditions over this 32-year time span.

\section{Results}

The broad impact of downsizing is demonstrated by calculating the number of workers employed at each mill by year during the study period (figure 1).

The average number of workers per mill was stable at approximately 600 until 1965 . During the "long boom" from 1965 to 1980 the number increased to approximately 700 workers per mill. The recession of 1980 witnessed the beginning of a rapid decline so that, between 1980 and 1996, the number of workers per mill dropped by $60 \%$, most of whom left the industry between 1980 and 1986.

For a picture of how the work environment was restructured following the recession in the early $1980 \mathrm{~s}$, changes in the relative proportions of job types for the cohort study sawmills are illustrated in figure 2 .

Between 1965 and 1995 the proportion of unskilled production jobs (mainly laborers working either on the assembly line or off it) remained relatively stable, representing between $40 \%$ to $50 \%$ of all jobs. In contrast, the proportion of skilled production jobs increased from $12 \%$ of all jobs in 1965 to $35 \%$ in 1995 . The proportion of maintenance jobs decreased by half (from $30 \%$ to $15 \%$ ). Managerial jobs were also reduced from $9 \%$ in 1965 to $3 \%$ of all jobs in 1995, and clerical jobs were almost entirely eliminated by 1995 (0.8\% of jobs in 1995 compared with $10 \%$ in 1965). 
While the categories of jobs within the sawmills shifted dramatically, the absolute number of job titles also changed. In 1965 there were 86 job titles in the 14 study sawmills. By 1996, 20 were either eliminated or rare, while few job titles were added. This situation reflected what was observed from qualitative data obtained in this study, that is, that the restructuring was mainly due job attrition rather than the development of new technology and associated new job titles.

Figure 2 shows that most of the structural changes in jobs took place between 1975 and 1985. Given these basic structural shifts, what happened to psychosocial job conditions? They were estimated retrospectively for 1965 and currently for 1997 . The interrater reliability of the estimates for control, physical demand, noise, and coworker social support were "excellent" and for psychological demand were "good" for both the 1965 and the 1997 ratings (9).

Table 1 compares the psychosocial work conditions for the 60 job titles which remained in the sawmills with the 20 job titles eliminated or rare by 1997 . Estimates are for conditions in 1965 . The 20 rare or eliminated jobs had less control, less co-worker social support, less psychological demand, more physical demand, and more noise than the jobs retained by the industry. In order to show the change in psychosocial work conditions for jobs remaining in the industry (ie, job titles which survived

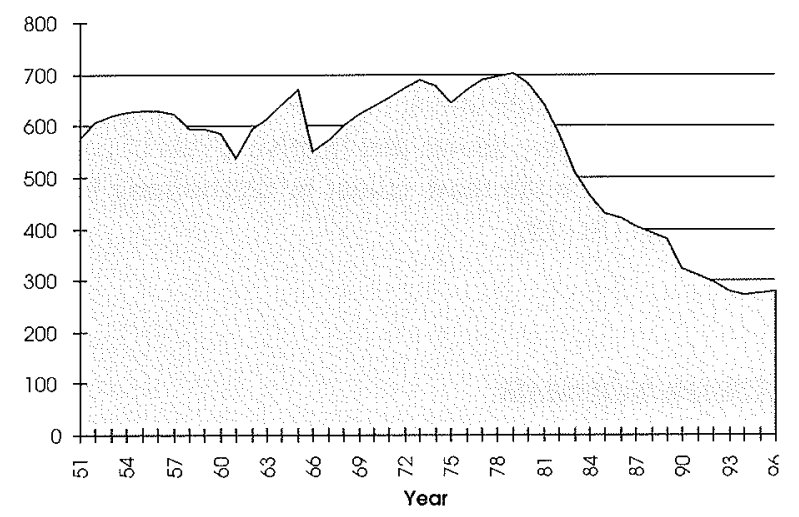

Figure 1. Number of workers per mill per year.

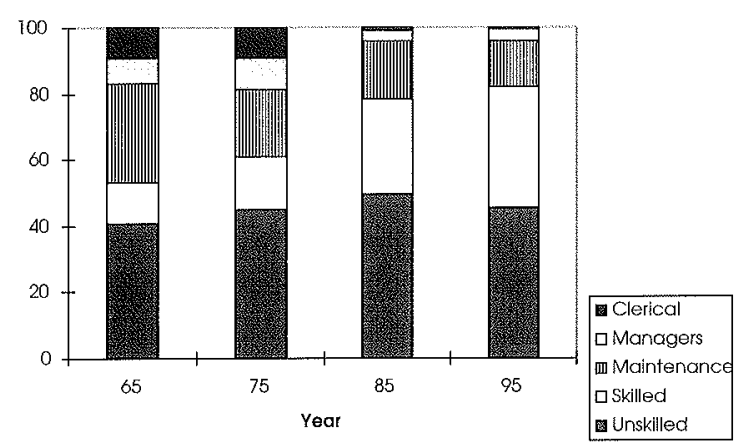

Figure 2. Changing proportion of major job categories by decade in the cohort study sawmills. the restructuring process), 1965 and 1997 estimations for surviving job titles were calculated and compared (table 2).

For jobs which remained in the industry psychological demand, physical demand, and noise decreased, and control increased, while co-worker social support remained the same. Thus physical and psychosocial conditions improved over time for jobs which were retained in the industry.

In order to understand these changes in psychosocial job conditions better, table 3 breaks them down by major job category. It shows control scores increasing more rapidly for managers than for other workers between 1965 and 1997. The psychological demand scores were not as widely dispersed by job title in 1965 as were the control scores. Yet reductions in psychological demand were greater among the nonmanagement job titles than among the managerial ones. In contrast, physical demand decreased for maintenance, skilled, and managerial categories but not for unskilled jobs.

For all control, psychological demand, and physical demand, the difference in scores between the unskilled and managerial job categories was greater in 1997 than it was in 1965 . These differences were minor for psychological and physical demand. However, the difference in the control scores between the unskilled and managerial jobs was 7.6 in 1965 and 8.7 in 1997, indicating that the disparity in control scores for managerial compared to unskilled jobs increased by $14.5 \%$ after the restructuring.

Table 1. Mean scores ${ }^{a}$ for the1965 psychosocial-physical work conditions of the eliminated or rare jobs in comparison with those remaining in the industry.

\begin{tabular}{lccc}
\hline Variable & $\begin{array}{c}\text { 20 eliminated } \\
\text { or rare jobs }\end{array}$ & $\begin{array}{c}60 \text { remaining } \\
\text { jobs }\end{array}$ & $\begin{array}{c}\text { Difference } \\
(\%)\end{array}$ \\
\hline Control & 16.8 & 20.2 & -20.2 \\
Psychological demand & 6.8 & 7.0 & -2.9 \\
Physical demand & 2.8 & 2.5 & +10.7 \\
Social support & 5.2 & 5.5 & -5.8 \\
Noise & 2.7 & 2.5 & +7.4 \\
\hline
\end{tabular}

a Scores obtained by averaging 1965 estimations obtained from the 4 expert job evaluators.

Table 2. Comparison of within-job scores for psychosocialphysical work conditions in 1965 and 1997 for the 60 remaining job titles.

\begin{tabular}{|c|c|c|c|c|}
\hline \multirow[t]{2}{*}{ Variable } & \multirow{2}{*}{$\begin{array}{c}1965 \\
\text { scores }\end{array}$} & \multirow{2}{*}{$\begin{array}{c}1997 \\
\text { scores }\end{array}$} & \multicolumn{2}{|c|}{ Difference } \\
\hline & & & Mean & $\%$ \\
\hline Control & 20.2 & 20.76 & +0.56 & +3.0 \\
\hline Psychological demand & 7.0 & 6.6 & -0.40 & -5.6 \\
\hline Physical demand & 2.5 & 2.34 & -0.16 & -6.4 \\
\hline Social support & 5.5 & 5.5 & 0.00 & 0.0 \\
\hline Noise & 2.5 & 2.43 & -0.07 & -3.0 \\
\hline
\end{tabular}


Table 3. Change in the scores for the psychosocial-physical work conditions by job category from 1965 to 1997 for the 60 remaining jobs. ${ }^{\mathrm{a}}$

\begin{tabular}{|c|c|c|c|c|c|c|c|c|c|}
\hline \multirow[t]{2}{*}{ Job type } & \multicolumn{3}{|c|}{ Contral } & \multicolumn{3}{|c|}{ Psychological demand } & \multicolumn{3}{|c|}{ Physical demand } \\
\hline & 1965 & 1997 & $\begin{array}{c}\text { Change in score } \\
\text { from } 1965 \text { to } \\
1997(\%)\end{array}$ & 1965 & 1997 & $\begin{array}{c}\text { Change in score } \\
\text { from } 1965 \text { to } \\
1997(\%)\end{array}$ & 1965 & 1997 & $\begin{array}{l}\text { Change in score } \\
\text { from } 1965 \text { to } \\
1997(\%)\end{array}$ \\
\hline Unskilled & 17.6 & 18.0 & +2.2 & 6.9 & 6.5 & -6.8 & 2.7 & 2.7 & 0 \\
\hline Skilled & 19.9 & 20.5 & +2.9 & 7.0 & 6.6 & -6.6 & 2.4 & 2.1 & -14.0 \\
\hline Maintenance & 23.9 & 24.4 & +2.1 & 6.8 & 6.5 & -4.1 & 2.6 & 2.4 & -7.0 \\
\hline Managers & 25.2 & 26.7 & +5.6 & 7.8 & 7.5 & -2.9 & 1.9 & 1.7 & -14.0 \\
\hline
\end{tabular}

a The scores in this table are based on the 60 job titles which remained in the industry.

\section{Discussion}

The major limitations of this investigation are useful to consider at the outset of this discussion. The assessment of psychosocial work conditions in this investigation was conducted at "arm's length" in 2 senses. First, expert raters were asked to estimate conditions in a "generic" as opposed to a "real" sawmill in order to obtain an industry average. The arm's length estimation method means that the psychosocial conditions of work in any of the 14 study sawmills may differ from the average to an unknown extent.

These estimations were at arm's length in a 2nd sense since workers' perceptions of their own psychosocial work conditions were not included. The expert rater method contains the potential for misclassification both at the level of the sawmill and the individual. This potential is likely higher for the retrospective assessments (in 1965) than the ones performed currently (in 1997).

This investigation shows that $60 \%$ of the sawmill cohort was eliminated between 1981 and 1997, as was approximately $1 / 4$ of the job titles. Most of the eliminated job titles were heavy, noisy, low-control, unskilled jobs, because restructuring largely involved the mechanization of front- and tail-end machine tending functions formerly performed by unskilled assembly-line labor. These unskilled machine-tending job titles were increasingly telescoped into the job description of the skilled machine operators working the new machines. This change is reflected in the tripling in the proportion of skilled production jobs between 1965 and 1996.

Did the elimination of jobs titles with the worst tasklevel psychosocial job conditions mean that psychosocial and physical work conditions improved in the restructured sawmills? The within-job title change in scores from 1965 to 1997 indicates that physical demand was reduced by approximately $6 \%$. The reduction in physical demand was greatest for managers and skilled production workers. However, reduced physical demand may not be associated with an improvement in health as sedentary blue-collar jobs have been consistently associated with higher coronary heart disease mortality and morbidity in a range of working populations $(13,14)$.
Psychological demand scores were also reduced by approximately $6 \%$ with the greatest reduction occurring among unskilled workers and the least among managers. For all the jobs, the control scores increased, with the greatest increases observed for managers. Job strain (psychological demand divided by control) was lower for all the job categories in 1997 than it was in 1965. Co-worker social support remained unchanged across the 2 time periods.

While these data indicate improvement in the psychosocial conditions of work, it should be noted that the gradient in control across job categories was steeper in 1997 than in 1965. Therefore, the overall improvement in control has been accompanied by increased disparity in control between jobs which are highest and lowest in the sawmill job hierarchy. This increased disparity is the result of a greater relative increase in control for managerial than for unskilled jobs. This finding may have important health implications because several population health studies have shown that relative levels of control at work may be the most salient in determining health outcomes $(15-18)$.

\section{Acknowledgments}

The British Columbia Health Research Foundation, Center for Health Services and Policy Research at the University of British Columbia, Forest Renewal BC, Institute of Work and Health (Toronto), and the Canadian Institute of Advanced Research (Toronto) are acknowledged for their financial support.

\section{References}

1. Hobsbawm EA. Age of extremes: the short twentieth century, 1914-1991. London: Abacus, 1994.

2. Rifkin J. The end of work: the decline of the global labour force and the dawn of the post-market era. New York (NY): Putnam's Sons, 1996. 
3. Hayter R, Barnes TJ. Labour market segmentation, flexibility, and recession: a British Columbian case study. Environ Plannn 1992;10:333-53.

4. Allen D, Cohen C. Forestry sector labour adjustment study. Ottawa: Employment \& Immigration Canada, Industry, Science \& Technology Canada Labour Canada, Ministry of Forestry, 1988.

5. Barnes TJ, Hayter R. The little town that did: Flexible accumulation and community response in Chemainus, British Columbia. Regional Studies 1992;26:647-63.

6. Barnes TJ, Hayter R. British Columbia's private sector in recession, 1981-86: employment flexibility without trade diversification. BC Stud 1993;98:20-42.

7. Hertzman C, Teschke K, Ostry A, Dimich-Ward H, Kelly S, Spinelli $\mathbf{J}$, et al. Cancer incidence and mortality in sawmill workers exposed to chlorophenols. Am J Public Health 1996;87:71-9.

8. Teschke K, Hertzman C, Fenske R, Jin A, Ostry A, van Netten $\mathrm{C}$, et al. A history of process and chemical change for fungicide application in the Western Canadian lumber industry: what can we learn? Occup Environ Hyg 1994;9:984-93.

9. Ostry A, Marion S, Green L, Demers P, Hertzman C. Measuring psychosocial job strain using experienced job evaluators. Toronto: Institute of Work and Health, 1999. Working papers series, no 92.

10. Karasek R, Theorell T. Healthy work. New York (NY): Basic Books, 1990.

11. Karasek R, Gordon G, Pietrokovsky C, Frese M, Pieper C,
Schwartz J, et al. Job content instrument: questionnaire and users' guide. Lowell (MA): University of Massachusetts, 1985.

12. Johnson JV, Hall EM, Theorell T. Combined effects of job strain and social isolation on cardiovascular disease morbidity and mortality in a random sample of Swedish male working population. Scand J Work Environ Health 1989;15:271 -9.

13. Powell KE, Paffenbarger RS. Workshop on epidemiologic and public health aspects of physical activity and exercise: a summary. Public Health Rep 1985;100:118-26.

14. Kristensen TS. cardiovascular diseases and the work environment: a critical review of the epidemiological literature on non-chemical factors. Scand J Work Environ Health 1989; $15: 165-79$

15. Marmot MG, Davey-Smith G, Stansfeld S, Patel C, North F, Head J, et al. Health inequalities among British civil servants: the Whitehall II study. Lancet 1991;337:1387-93.

16. Marmot MG, Bobak M, Davey-Smith G. Explanations for social inequalities in health. In: Amick III BC, Levine S, Tarlov AR, Walsh DC, editors. Society and health. Oxford: Oxford University Press, 1995.

17. Wilkinson RG. Income distribution and life expectancy. BMJ 1992;304:165-8.

18. Wilkinson R. Health Ineqalities: relative or absolute material standards?. BMJ 1997:314:591—5.

Received for publication: 21 May 1999

\section{Appendix}

\section{3-item questionnaire}

(Raters responded to the 13 statements with 1 of the following answers: Strongly disagree, disagree, agree, strongly agree)

1. The job required learning new things.

2. The job involved a lot of repetitive work.

3. The job required a high level of skill.

4 . The job had a variety of tasks.

5. The worker had a lot to say about what happened on the job.

6. On this job, the worker had a lot of freedom to decide how to do the work.

7. The job did not involve an excessive amount of work.

8. The worker had enough time to get the job done.

9. The job was free from conflicting demands.

10. The job required lots of physical effort.

11. The worker could leave this job to talk with co-workers.

12. The worker could interact with co-workers while they worked.

13. The job was noisy. 